\title{
Development of Brush Border Peptidases in Human and Rat Small Intestine during Fetal and Neonatal Life
}

\author{
SALVATORE AURICCHIO, ${ }^{(45)}$ ANTONIO STELLATO, AND BASILIO DE VIZIA \\ Department of Pediatrics, II Faculty of Medicine, University of Naples, Naples, Italy, and Consiglio Nazionale delle \\ Ricerche, Program of Preventive Medicine (Project of Perinatal Medicine), Rome, Italy
}

\begin{abstract}
Summary
The cytosol peptidase activities hydrolyzing glycyl-L-leucine and L-leucyl-glycyl-glycine as well as the activities of the brush border peptidases (oligoaminopeptidase, aminopeptidase $A, \gamma$-glutamyltranspeptidase, dipeptidyl-aminopeptidase IV, and carboxypeptidase) are present in rat fetuses during the early differentiation of the intestine (17th to 19th days of fetal life); they increase then at a different rate, reaching a maximum at various times, in the second and third wk after birth, and then decrease to the adult values during the first month of postnatal life. Only the oligoaminopeptidase activity increases steadily after birth, reaching maximal activity in the last decade of the first month.

In human fetuses aged between 8 and 22 wk, the $\gamma$-glutamyltranspeptidase was the only brush border peptidase found to be higher than in adults and children. On the other hand, the aminopeptidase $A$ is remarkably reduced. The dipeptidylaminopeptidase IV and the carboxypeptidase are already at adult level in the youngest fetuses, and the oligoaminopeptidase increases during the period of fetal life studied; at the end of this period, the enzyme activity does not differ from the values found in children and adults.
\end{abstract}

The small intestine of the term and preterm newborn should, therefore be able, with some possible exceptions, to efficiently digest peptides.

\section{Speculation}

The studied intracellular and brush border peptidases are already well developed in preterm babies, with the only exception of the aminopeptidase $A$. The importance that the low activity of this enzyme may have in the nutrition of preterm (and term) neonates is not known. If this enzyme, among the different-brush border peptidases, has a unique importance in digesting glutamyl-peptides, one may suppose that digestibility of these peptides is reduced at birth.

Dipeptides and tripeptides may enter the enterocyte $(25,29,30)$ through a transport system of broad specificity. There they are hydrolyzed by different cytosol enzymes, three of which, two dipeptidases $(10,27,28,37)$ and one tripeptidase $(12)$, have been purified.

Dipeptides and tripeptides, as well as larger peptides, may also be hydrolyzed in the brush border membrane, where the following peptidases are present: (1) the oligoaminopeptidase $(15,16,20$, 36 ), which is able to hydrolyze di-and oligopeptides up to at least octapeptides (20); (2) a dipeptidylamino-peptidase IV $(1,3,5,38)$, which is able to release $\mathrm{N}$-terminal dipeptides from peptides that have penultimate proline, alanine, or leucine residues (40); (3) the aminopeptidase $\mathrm{A}(1,2,3,5)$, probably involved in the digestion of oligopeptides containing glutamic (and aspartic) acid (19); (4) a carboxypeptidase $(1,3,5)$, which is probably able to hydrolyze the C-terminal residue from a large series of oligopeptides that have proline as the C-penultimate aminoacid (11); (5) the $\gamma$ glutamyltranspeptidase $(2,4,6,8)$, presumed to be involved in the transport of amino acids and dipeptides across the brush border $(14,39)$. Suitable substrates for the assay of these five brush border peptidases are: L-leucyl-, glycyl-L-prolyl-, $\alpha$-L-glutamyl- $\beta$-naphthylamide, $N$-CBZ-L-prolyl-L-leucine, and $\gamma$-L-glutamyl- $\beta$-naphthylamide, respectively.

The oligoaminopeptidase and the $\gamma$-glutamyltranspeptidase are the only brush border peptidases whose developmental pattern has been studied in human $(4,18)$, rat $(26)$, and guinea pig (8) intestine.

We investigated the development of the brush border peptidases in the human fetus and in the rat during fetal and neonatal life.

\section{MATERIALS AND METHODS}

\section{HUMAN INTESTINAL ENZYMES}

Intestine from 38 human fetuses between the ages of 8 and 22 wk of gestation was obtained after legal abortions. The small intestine was immediately removed and frozen. After thawing, the small intestine from fetuses above $20 \mathrm{wk}$ was opened, the intestinal contents were removed, and the mucosa was scrapped off and homogenized in distilled water $(4 \mathrm{~g} / 100 \mathrm{ml})$ with a motor-driven Teflon-glass homogenizer. The homogenate was centrifuged at $1000 \times g$ for $10 \mathrm{~min}$. The supernatant fluid, which contained more than $90 \%$ of the enzymatic activity, was used for enzyme assay and for the determination of protein. The small intestine of fetuses below 20 wk was homogenized without removing the intestinal content.

The homogenate of the whole small intestine of 22 fetuses aged 15 wk or less was used, whereas in the remaining older fetuses, the homogenate of the proximal third was prepared and used for the studies on the development of enzyme activities in fetuses of various ages.

The small intestine of some fetuses were cut into three equal parts to study the enzyme distribution along the small intestine.

Peroral small intestinal biopsies were obtained for diagnostic purposes from the last part of the duodenum immediately before the flexure duodeno-jejunalis from 13 children between the ages of 7 months and 11 years (mean age, 3 years) affected by unspecific chronic diarrhea with histologically normal mucosa.

Macroscopically normal strips of intestinal mucosa weighing 100 to $200 \mathrm{mg}$ were obtained from the proximal jejunum (approximately $10 \mathrm{~cm}$ from the ligament of Treitz) of 15 consenting adult patients who underwent lower partial gastrectomy and gastrojejunostomy for duodenal ulcer.

\section{RAT INTESTINAL ENZYMES}

Fetuses from the 17th day of gestation up to birth were removed by cesarean section from Wistar rats under ether anesthesia. 
During the first day of life, some rats were killed before the first feed (stomach empty), and some after (stomach full of colostrum). Five newborns were left to each mother. Rats were killed each day after birth up to the 12th day of postnatal age, and on days $14,15,17,19,20,21,24,27$, and 30 . Two or three intestines from fetuses and newborns up to the fifth day after birth were pooled: from the sixth day after birth, single intestines were homogenized. Nine rats weighing approximately $200 \mathrm{~g}$ each were also killed to establish the normal adult values. All animals were fed ad libitum a Mil diet or maternal milk until death; they were all killed at 10 AM to minimize any variations of the enzyme activities due to the circadian rhythm (7).

Small and large intestine from fetuses were homogenized together; after birth, only the small intestine was homogenized. From the third day after birth, the intestinal contents were removed; from the 1lth day after birth, the small intestinal mucosa was scraped off.

The intestinal tissues were immediately processed for the assay of glycyl-L-leucine and L-leucyl-glycyl-glycine hydrolase activities because the cytosol enzymes hydrolyzing these substrates were labile at $-20^{\circ} \mathrm{C}$. For all other enzymatic activities, the intestine was frozen at $-20^{\circ} \mathrm{C}$ for not more than $1 \mathrm{wk}$; the enzymatic activities were stable under these conditions.

\section{FRACTIONATION STUDIES}

Subcellular fractions from the total homogenate of human fetal intestine and from adult rats were prepared according to Schmitz et al. (34).

\section{ENZYME ASSAYS}

The human enzymes were measured as previously reported (1, 5). The same methods were used to assay the rat enzymes; optimal $\mathrm{pH}$ and ion activation were determined in preliminary studies.

The optimal $\mathrm{pH}$ for the hydrolysis in the homogenate of adult rat small intestine of different substrates in $100 \mathrm{mM}$ buffers were the following: in Tris- $\mathrm{HCl}$ buffer, $\mathrm{pH} 8$ for $\alpha$-L-glutamyl- $\beta$-naphthylamide in the presence of $5 \mathrm{mM} \mathrm{CaCl}$ and for L-leucyl-glycylglycine and $\mathrm{pH} 7$ for L-leucyl- $\beta$-naphthylamide; in potassium phosphate buffer, pH 8 for glycyl-L-prolyl- $\beta$-naphthylamide and for glycyl-L-leucine; in veronal buffer, $\mathrm{pH} 7.8$ for $N$-CBZ-L-prolylL-leucine in the presence of $1 \mathrm{mM} \mathrm{CaCl}_{2}$.

The homogenate for the assay of the carboxypeptidase activity was diluted to $1 \%(\mathrm{w} / \mathrm{v})$ or less, as higher concentrations gave lower results.
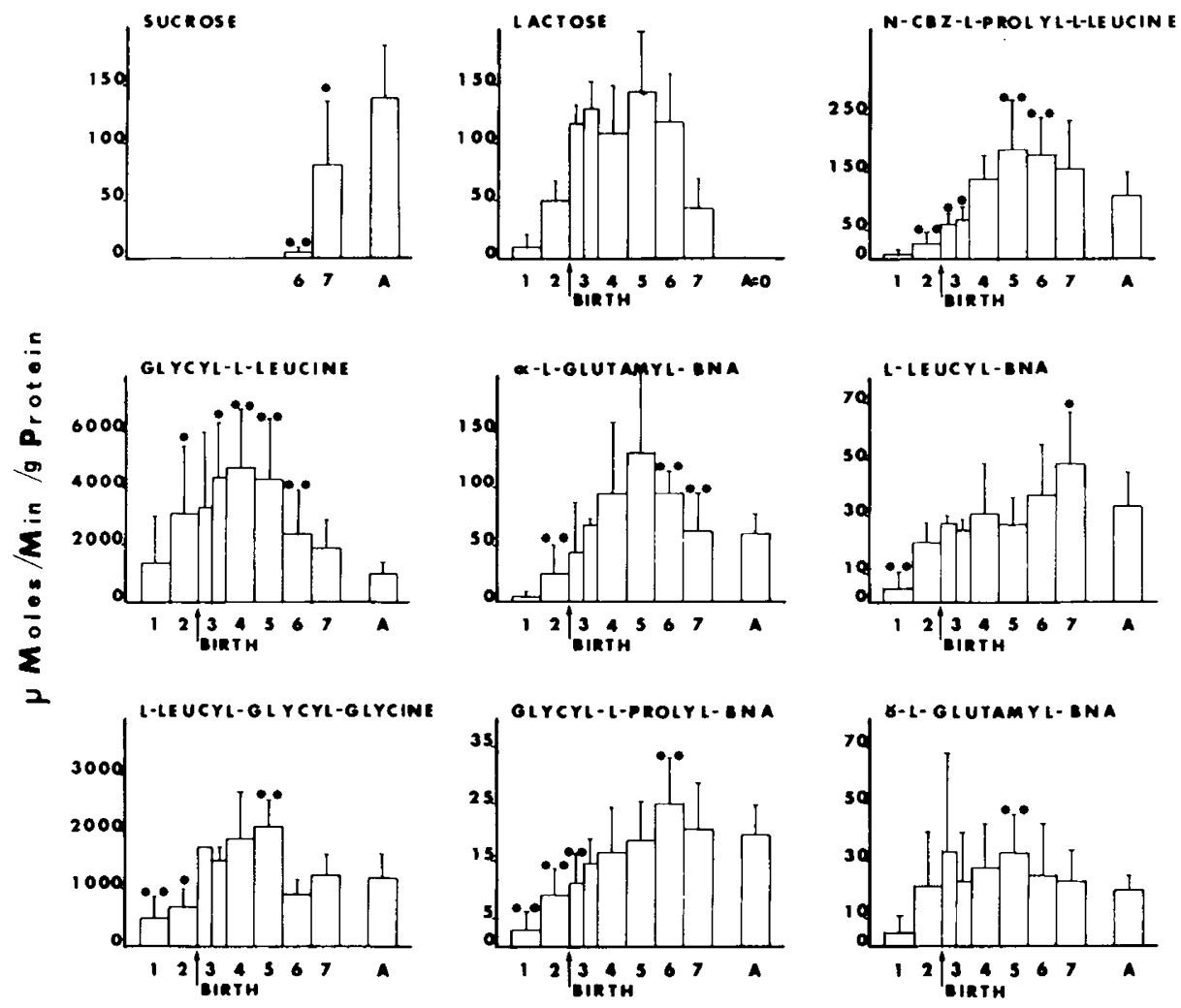

\section{AGE GROUPS}

Fig. 1. Developmental pattern of disaccharidase and peptidase activities of rat intestine (units/g protein: mean \pm S.D.). The fetal period was subdivided into the early differentiation of the small intestine (17th to 19th days) and late gestation (20th to 22nd days). The postnatal period was subdivided after the first day into the early and late breast feeding (second to fifth and sixth to ninth days, respectively), corresponding to the maximal values of lactase activity and to the absence of sucrase, and into the weaning (10th to 19th days) and the solid diet (20th to 30th days) periods, corresponding to the lowering of the lactase activity and the increase of sucrase.

The age groups ( $1=17$ to 19 days before birth; $2=20$ to 22 days before birth; $4=2$ to 5 days after birth; $5=6$ to 9 days after birth) are represented by three animals or groups of animals for each day. The age group $6=10$ to 19 days after birth is represented by three animals for each of the following days: $10,11,12,14,15,17$, and 19 . The age group $7=20$ to 30 days after birth is represented by three animals for each of the following days: 20,21 , 24,27 , and 30 . On the first day after birth (age group 3), animals were divided in two groups before (stomach empty; two animals) and after (stomach full of colostrum; three animals) the first meal. $A$, adults; nine animals. ${ }^{*}$, difference with the adult value statistically significant $(P<0.05)$; ${ }^{* *}$, difference with the adult value statistically significant $(P<0.01)$. 
PAPAIN, TRYPSIN, AND TRITON SOLUBILIZATION

These were carried out according to published methods $(2,24)$.

\section{REAGENTS}

Substrates and reagents used were as described in previous reports $(1,2,5)$.

\section{RESULTS AND DISCUSSION}

\section{RAT ENZYMES}

Subcellular Localization. The enzymatic hydrolysis of glycyl-Lleucine and L-leucyl-glycyl-glycine is mainly due to soluble enzymes. The recoveries in the cytosol expressed as percentage of the activities in the homogenate were $98 \pm 8$ and $103 \pm 15$, respectively (mean \pm S.E. of four different animals). Therefore, by using these substrates we may measure in total homogenate the activity of soluble peptidases; by using glycyl-L-leucine as substrate we most probably measure the activity of two soluble dipeptidases, the enzymes III and IV of Schiller et al. (33), and by using L-leucyl-glycyl-glycine, we mainly measure the activity of a tripeptidase, the enzyme I of Schiller et al. (33).

The enzymatic activities hydrolyzing the $\beta$-naphthylamides of amino acids as well as $N$-CBZ-L-prolyl-L-leucine are, on the contrary, mainly located in the brush border. The recoveries in the brush border fraction expressed as percentage of the activities in the homogenate (mean \pm S.E. of four different animals) were: $50 \pm 9$ for the hydrolysis of sucrose; $50 \pm 20$ for the hydrolysis of L-leucyl- $\beta$-naphthylamide; $37 \pm 9$ for the hydrolysis of $\alpha$-L-glutamyl- $\beta$-naphthylamide; $43 \pm 3$ for the hydrolysis of glycyl-Lprolyl- $\beta$-naphthylamide; $31 \pm 8$ for the hydrolysis of $N$-CBZ-Lprolyl-L-leucine; $30 \pm 7$ for the hydrolysis of $\gamma$-L-glutamyl- $\beta$ naphthylamide; purification in the brush border compared to homogenate ranged from 8- to 14-fold for the different enzymatic activities. Therefore, by using these substrates we may measure in total homogenate the activity of brush border peptidases: oligoaminopeptidase, aminopeptidase A, dipeptidylaminopeptidase IV, carboxypeptidase, and $\gamma$-glutamyl-transpeptidase respectively.

Development. It has been thus possible to obtain complete developmental curves of cytosol and brush border peptidases in rats during fetal life and after birth. These curves show clear differences in the developmental pattern of the different enzymes (Fig. 1). Previous studies of Lindberg and Owman (23) together with the results reported in Fig. 1 show that in rats the activities of cytosol enzymes on dipeptides (L-alanyl-L-glutamic acid, Lalanyl-L-proline, glycyl-glycine, glycyl-L-leucine, and glycyl-L-valine) as well as that on L-leucyl-glycyl-glycine are present in the homogenate of fetal whole small intestine already at the 15th to 18th days and that they rapidly increase as soon as the fetal mucosa differentiates. Similar results have been obtained for $\mathrm{L}$ alanyl-L-glutamic acid, L-alanyl-L-proline, and glycyl-L-leucine hydrolysis in pig fetuses (22) and for the glycyl-L-proline hydrolysis in rabbit fetuses (30).

As regards the postnatal development of these enzymatic activities in the rat, we found that the glycyl-L-leucine dipeptidase and L-leucyl-glycyl-glycine hydrolase activity remains high during the first 9 days after birth and then decreases rapidly to the adult values. Lindberg and Owman (23) observed, on the contrary, after the newborns had suckled, within a few hours of birth, an abrupt and significant fall to the relatively low adult level for all the studied dipeptidase activities (L-alanyl-L-glutamic acid, glycyl-glycine, glycyl-L-leucine, and glycyl-L-valine hydrolase activities) with the exception of the L-alanyl-L-proline dipeptidase activity, which declines more slowly postnatally and reaches low adult level only during the third wk postpartum.

An increase in the fourth postnatal wk has been found in rat small intestine for the hydrolysis of L-alanyl-L-phenylalanine (17) as well as for that of glycyl-glycyl-glycine measured in proximal jejunum (26).
Table 1. Disaccharidases and peptidase specific activities (units/g protein) of small intestine of human fetuses (age between 8 and 22 $w k$ ), children (age between 7 months and 14 years; mean age, 3 years) and adults

\begin{tabular}{lrrrrr}
\hline \multicolumn{1}{c}{ Substrates } & Mean \pm 1 S.D. & Range & $n$ & $P$ \\
\hline Sucrose $^{1}$ & & & & & \\
& & & & & \\
Fetuses & $54 \pm 27$ & $7.7-151$ & 31 & $<0.01^{2}$ \\
Children & $83.2 \pm 29$ & $39-126$ & 13 & \\
Adults & $79.5 \pm 27$ & $30-128$ & 15 &
\end{tabular}

$\alpha-\mathrm{L}$-Glutamyl- $\beta$ -

naphthylamide ${ }^{1}$

$\begin{array}{lrcrr}\text { Fetuses } & 3.5 \pm 1.7 & 1.4-7 & 29 & <0.001^{2} \\ \text { Children } & 13.4 \pm 3.2 & 9.3-17 & 13 & \\ \text { Adults } & 16.1 \pm 5.9 & 10-20.7 & 15 & \end{array}$

Glycyl-L-propyl- $\beta$ -

naphthylamide ${ }^{1}$

$\begin{array}{lcccc}\text { Fetuses } & 15.7 \pm 6.2 & 4-27.3 & 31 & <0.05^{2} \\ \text { Children } & 11.8 \pm 4.1 & 5.6-19.7 & 13 & \\ \text { Adults } & 13.9 \pm 3.3 & 9-21 & 15 & \end{array}$

$\gamma$-L-Glutamyl- $\beta$ -

naphthylamide ${ }^{1}$

$\begin{array}{lccrr}\text { Fetuses } & 30.2 \pm 20.8 & 9.5-9.8 & 30 & <0.001^{2} \\ \text { Children } & 7 \pm 2.4 & 4.7-10 & 4 & \\ \text { Adults } & 11.6 \pm 3 & 7.2-16 & 10 & \end{array}$

L-Leucyl- $\beta$-naphthylamide ${ }^{1}$

$\begin{array}{lrcrl}\text { Fetuses }<13 \mathrm{wk} & 26 \pm 10 & 8.5-47.2 & 20 & <0.01^{2} \\ \text { Fetuses }>13 \mathrm{wk} & 56.9 \pm 30 & 20.1-129.5 & 11 & \\ \text { Children } & 40.4 \pm 12 & 26-60 & 13 & \\ \text { Adults } & 41.1 \pm 16 & 25.5-85 & 12 & \end{array}$

Lactose $^{1}$

$\begin{array}{lcccc}\text { Fetuses }<13 \mathrm{wk} & 3.1 \pm 2 & 1-9.5 & 20 & <0.001^{3} \\ \text { Fetuses }>13 \mathrm{wk} & 10.5 \pm 4.9 & 1.3-18.7 & 11 & <0.01^{3} \\ \text { Adults }^{4} & 23.6 \pm 9.8 & 10.5-36.7 & 10 & \end{array}$

$N$-CBZ-L-Prolyl-Lleucine

$\begin{array}{lrrr}\text { Fetuses }^{5} & 14.3 \pm 4.5 & 10-25 & 10 \\ \text { Adults } & 14.3 \pm 3.4 & 9.4-21 & 11\end{array}$

${ }^{1}$ The homogenate of the total small intestine was used in 22 fetuses aged $15 \mathrm{wk}$ or less, whereas in nine older fetuses, the values of the proximal third are reported. In these fetuses, there was no statistically significant difference between the enzymatic activities of the proximal third and of the total small intestine.

${ }^{2}$ Statistical significance of the difference with the values obtained in children.

${ }^{3}$ Statistical significance of the difference with the values obtained in adults.

${ }^{4}$ Adults with isolated acquired lactase deficiency (lactase activity $<10$ units/g protein) were excluded.

${ }^{5}$ Fetal age: $12 \mathrm{wk}(n=3)$; 13 wk $(n=3)$; $14 \mathrm{wk}(n=1) ; 16 \mathrm{wk}(n=2)$; $20 \mathrm{wk}(n=1)$.

The activities of the brush border peptidases (Fig. 1) are also present in the rat fetuses during the early differentiation of the intestine (17th to 19th days of fetal life), but they increase at a different rate, reaching a maximum at various times, in the second 
and third wk after birth, and then decreasing to the adult values during the first month of postnatal life. Only the oligoaminopeptidase activity (Fig. 1; Ref. 26) increases steadily after birth reaching maximal activity in the last decade of the first month.

The contemporary study of different intracellular and brush border peptidases in developing rat intestine appears to be an interesting tool for studying the control mechanisms of the 2 ways of enterocyte peptide digestion and absorption: the intracellular way, coupled to the transport system for peptides, and the brush border way, coupled to the transport system for aminoacids, and for peptides. The transport systems for most amino acids and peptides have been found to develop early in the fetal intestine of animals, with a higher activity in the perinatal period than in adults (30).

The differences in the developmental pattern of the various peptidase activities may be due not only to a different control of the enzyme activities in the enterocyte but also to an age-dependent variation of the type of enterocyte present along the villuscrypt axis with different levels of peptidase activities (35) or to the presence of peptidase activities not only in the enterocyte, but also in other mucosal cells $(41,42)$; variations of the enzymatic activity of the total mucosa may, therefore, also be due to variations of the mucosal content of cells other than the enterocyte (43).

\section{HUMAN BRUSH BORDER ENZYMES}

Distribution along the Fetal Intestine. The disaccharidase activities are equally active in the proximal and distal third, whereas the peptidases are more active in the distal third than in the proximal one; these differences, however, are not statistically significant (Table 2).

The disaccharidase and peptidase activities in the colon of a 16wk-old fetus were similar to that found in the small intestine. The specific activities (units/g protein) for the hydrolysis of the different substrates were: sucrose, 103 ; lactose, $8 ; \alpha$-L-glutamyl- $\beta$-naphthylamide, 6 ; L-leucyl- $\beta$-napthylamide, 69 ; glycyl-L-prolyl- $\beta$ naphthylamide, $15 ; \gamma$ - $\mathrm{x}$-glutamyl- $\beta$-naphthylamide, 22 . The fetal colon is also rich in soluble peptidases (21) and disaccharidases (9), showing the enzymatic and morphologic features of the small intestine (21).

Subcellular Localization and Solubilization. In two 13-wk-old fetuses, the percentage in the brush border of the peptidase activities hydrolyzing the $\beta$-naphthylamides of amino acids as well as $N$-CBZ-L-prolyl-L-leucine was found to be similar to that of the sucrase (Table 3); it ranged between 40 and $60 \%$, with a 7 to 12-fold increase of the specific activities, as compared to that of the total homogenate. More than $70 \%$ of the particle-bound peptidase activities were solubilized by papain or Triton X-100, whereas trypsin hydrolysis had a lower solubilizing effect.

Development. We studied only fetuses aged between 8 and 22 wk, thus the developmental curve of the different enzymes is incomplete.

The specific activities of the studied enzymes were plotted against the fetal age, and the regression lines were calculated by the least squares method (13). Only the lactase and the oligoaminopeptidase activities were found to increase significantly during the period of fetal life studied, the slope of the regression lines being significantly different from zero when calculated by Student's $t$ test $(P<0.01)$. The other enzyme activities showed no age-dependent variation. Therefore, in the comparison of the enzymatic activities between fetuses and children for the lactase and oligoaminopeptidase activities, the fetuses were subdivided into two age groups (fetal age 13 wk and less; and fetal age above $13 \mathrm{wk}$ ) (Table 1).

Only the $\gamma$-glutamyl-transpeptidase was found to be higher in fetuses than in adults and children, confirming the results of a previous study (4). The aminopeptidase A is on the contrary remarkably reduced during the whole fetal period; the dipeptidylaminopeptidase IV and the carboxypeptidase are already at adult level in the youngest fetuses; the oligoaminopeptidase increases during the period of fetal life studied, and this confirms previous results (18); at the end of this period the enzyme activity does not differ from the values found in children and adults.

Previous studies have also demonstrated that dipeptidase and

Table 2. Distribution of disaccharidase and peptidase specific activities along the small intestine of eight human fetuses aged between 16 and 22 wk (units $/ g$ protein) ${ }^{1}$

\begin{tabular}{|c|c|c|c|}
\hline \multirow[b]{2}{*}{ Substrates } & \multicolumn{3}{|c|}{ Fetal intestine } \\
\hline & $\begin{array}{l}\text { Proximal } \\
\text { third }\end{array}$ & $\begin{array}{l}\text { Intermediate } \\
\text { third }\end{array}$ & Distal third \\
\hline Sucrose & $67 \pm 43^{2}$ & $66 \pm 32$ & $56 \pm 39^{2}$ \\
\hline $\begin{array}{l}\alpha \text {-L-Glutamyl- } \beta- \\
\text { naphthylamide }\end{array}$ & $4 \pm 2$ & $6 \pm 4$ & $10 \pm 6$ \\
\hline $\begin{array}{c}\text { Glycyl-L-prolyl- } \beta \text { - } \\
\text { naphthylamide }\end{array}$ & $15 \pm 6$ & $27 \pm 13$ & $37 \pm 26$ \\
\hline $\begin{array}{c}\gamma \text {-L-Glutamyl- } \beta \text { - } \\
\text { naphylamide }\end{array}$ & $28 \pm 16$ & $66.5 \pm 90$ & $73 \pm 90$ \\
\hline $\begin{array}{l}\text { L-Leucyl- } \beta \text {-naph- } \\
\text { thylamide }\end{array}$ & $56 \pm 30$ & $77 \pm 45$ & $84 \pm 44$ \\
\hline Lactose & $11 \pm 4.5$ & $11 \pm 4.5$ & $9.5 \pm 5.8$ \\
\hline
\end{tabular}

${ }^{\mathrm{l}}$ Fetal age: $16 \mathrm{wk}(n=2)$; $17 \mathrm{wk}(n=1) ; 18 \mathrm{wk}(n=1) ; 21 \mathrm{wk}(n=1)$; 22 wk $(n=3)$. Differences between the proximal and the distal third of the small intestine were not significant, with the only exception of the glycyl-L-prolyl- $\beta$-naphthylamide hydrolase activity $(P<0.05)$.

${ }^{2}$ Mean \pm 1 S.D.

Table 3. Specific activities and recoveries of sucrase and peptidases in homogenate and subcellular fractions of the small intestine of two human fetuses (age, $13 \mathrm{wk}$ ). The single values are reported.

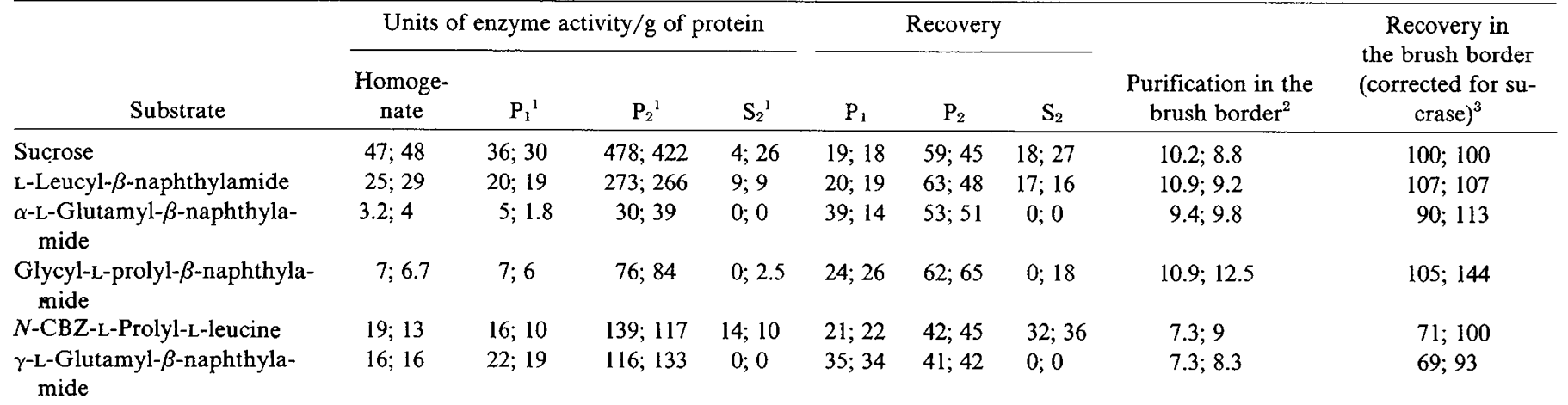

\footnotetext{
${ }^{1}$ Subcellular fractions obtained according to Schmitz et al. (34); $\mathrm{P}_{2}=$ brush border; $\mathrm{P}_{1}=$ other cellular membranes; $\mathrm{S}_{2}=$ final supernatant.

${ }^{2}$ Specific activity in the homogenate is equal to 1.

${ }^{3}$ Calculated assuming a $100 \%$ recovery of sucrase activity in the brush border.
} 
glycyl-glycyl-glycine hydrolase activities are well developed at the fetal age of 11 to $14 \mathrm{wk}$ reaching levels comparable to those of the adult $(18,21,32)$.

We may therefore conclude that the studied intracellular and brush border peptidases are already well developed in preterm babies, the only exception being the aminopeptidase $\mathrm{A}$. The small intestine of the term and preterm newborn should, therefore, be able, with some possible exceptions, to efficiently digest and absorb peptides.

\section{REFERENCES AND NOTES}

1. Andria, G., Cucchiara, S., De Vizia, B., de Ritis, G., Mazzacca, G., and Auricchio S.: Brush border and cytosol peptidase activities of human small intestine in normal subjects and celiac patients. Pediatr. Res., 14: 812 (1980).

2. Andria, G., Marzi, A., and Auricchio, S.: $\alpha$-L-Glutamyl- $\beta$-naphthylamide hydrolase of rabbit small intestine. Localization in the brush border and separation from other brush border peptidases. Biochim. Biophys. Acta, 419: 42 (1976).

3. Auricchio, S., Andria, G., Greco, L., and Mazzacca, G.: Peptidases of brush border of human and rabbit small intestinal mucosa Pediatr. Res. (Abstract), 10: 879 (1976).

4. Auricchio, S., Ciccimarra, F., Vegnente, A., Andria G., and Vetrella, M.: Enzymatic activity hydrolyzing $\gamma$-glutamyl- $\beta$-naphthylamide in human intestine during adult and fetal life. Pediatr. Res., 7: 95 (1973).

5. Auricchio, S., Greco, L., De Vizia, B., and Buonocore, V.: Dipeptidyl-aminopeptidase and carboxypeptidase activities of the brush border of rabbit small intestine. Gastroenterology, 75: 1073 (1978).

6. Auricchio, S., Pierro, M., Andria, G., and de Ritis, G.: Enzymatic activities of the brush border membrane of rat intestine hydrolyzing- $\beta$-naphthylamides of amino acids, leucinamide and dipeptides. Biochim. Biophys. Acta, 274: 420 (1972).

7. Beam, H. E., and Henning, S. J.: Development of the circadian rhythm of jejunal sucrase activity in the weanling rat. Am. J. Physiol., 235: E437 (1978).

8. Cohen, M. I., Gartner, L. M., Blumenfeld, O. O., and Arias, I. M.: Gammaglutamyl transpeptidase: measurement and development in guinea pig small intestine. Pediatr. Res., 3: 5 (1969).

9. Dahlqvist, A., and Lindberg, T.: Development of the intestinal disaccharidase and alkaline phosphatase activities in the human foetus. Clin. Sci., 30: 517 (1966).

10. Das, M., and Radhakrishnan, A. N.: Glycyl-L-leucine hydrolase, a versatile "master" dipeptidase from monkey small intestine. Biochem. J., I35: 609 (1973).

11. Dehm P., and Nordwig A.: The cleavage of prolyl peptides by kidney peptidases Isolation of a microsomal carboxypeptidase from swine kidney. Eur. J. Biochem., 17: 372 (1970).

12. Doumeng, C., and Maroux, S.: Aminotripeptidase, a cytosol enzyme from rabbit intestinal mucosa. Biochem. J., 177: 801 (1979).

13. Fisher, R. A., and Yates, F.: Statistical Tables for Biological, Agricultural and Medical Research (Oliver and Boyd, London, 1957).

14. Garvey, T. Q., Hyman, P. E., and Isselbacher, K. J.: $\gamma$-Glutamyl-transpeptidase of rat intestine: localization and possible role in amino acid transport. Gastroenterology, 71: 778 (1976).

15. Gray, G. M., and Santiago, N. A.: Human jejunal surface amino-oligopeptidase: sequential and simultaneous action on a tetrapeptide and its products. Gastroenterology (Abstract), 66: 704 (1974).

16. Gray, G. M., and Santiago, N. A.: Intestinal surface aminooligopeptidase. I Isolation of two weight isomers and their subunits from rat brush border. J. Biol. Chem., 252: 4922 (1977).

17. Heizer, W. D., and Laster, L.: Hydrolases in the mucosa of rat small intestine for phenylalanine containing dipeptides. Biochim. Biophys. Acta, 185: 409 (1969).

18. Horingovà, A., Koldovsky, O., Jirsovà, V., Uher, J., Noack, R., Friedrich, M. and Schenk, G.: Proteolytic and peptidase activities of the small intestine of human fetuses. Gastroenterology, 51: 1023 (1966).

19. Kenny, A. J.: Proteinases associated with cell membranes. In: A. J. Barrett: Proteinases in Mammalian Cells and Tissues. pp. 393-444. (Elsevier, North Holland Biomedical Press, Amsterdam, 1977).

20. Kim, Y. S., Brophy, E. J., and Nicholson, J. A.: Rat intestinal brush border membrane peptidases. II. Enzymatic properties, immunochemistry and interactions with lectins of two different forms of the enzyme. J. Biol. Chem., 251: 3206 (1976)

21. Lindberg, T.: Intestinal dipeptidases: characterization, development and distribution of intestinal dipeptidases of the human foetus. Clin. Sci, 30:505 (1966)

22. Lindberg, T., and Karlsson, B. W.: Changes in intestinal dipeptidase activities during fetal and neonatal development of the pig as related to the ultrastructure of mucosal cells. Gastroenterology, 59: 247 (1970).

23. Lindberg, T., and Owman, C.: Intestinal dipeptidases. Development of dipeptidase activity in the small intestine of the rat as related to the development of the intestinal mucosa. Acta Physiol. Scand., 68: 141 (1966).

24. Marshall, J. J., Sturgeon, C. M., and Whelan, W. J.: Solubilization of porcine intestinal $\alpha$-glucosidases and evidence for the separate identities of isomaltase and limit dextrinase. Anal. Biochem., 82: 435 (1977).

25. Matthews, D. M.: Introduction. In: K. Elliott, M. O'Connor: Peptide Transport and Hydrolysis. pp. 5-14. Ciba Foundation Symposium 50 (new series), (Elsevier, Amsterdam, 1977).

26. Noack, R., Koldovsky, D., Friedrich, M., Heringovà, A., Jorsovà, V., and Schenk, G.: Proteolytic and peptidase activities of the jejunum and ileum of the rat during postnatal development. Biochem. J., 100: 775 (1966).

27. Norén, O., Sjöström, H., and Josefsson, L.: Studies on a soluble dipeptidase from pig intestinal mucosa. I. Purification and specificity. Biochim. Biophys. Acta, 327: 446 (1973).

28. Piggott, C. O., and Fottrell, P. F.: Purification and characterization from guinea pig intestinal mucosa of two peptide hydrolases which preferentially hydrolyze dipeptides. Biochim. Biophys. Acta, 391: 403 (1975).

29. Radhakrishnan, A. N.: Intestinal dipeptidase and dipeptide transport in the monkey and in man. In: K. Elliott, M. O'Connor: Peptide transport and hydrolysis. pp. 37-52. Ciba Foundation Symposium 50 (new series). (Elsevier, Amsterdam, 1977).

30. Rubino, A.: Absorption of amino acids and peptides during development. Mod. Probl. Paediatr., 15: 201 (1975).

31. Rubino A., Field M., and Shwachman H.: Intestinal transport of amino acid residues of dipeptides. I. Influx of the glycine residue of glycyl-L-proline across mucosal border. J. Biol. Chem., 246: 3542 (1971).

32. Rubino, A., Pierro, M., La Torretta, G., Vetrella, M., Di Martino, D., and Auricchio, S.: Studies on intestinal hydrolysis of peptides. II. Dipeptidase activity toward L-glutaminyl-L-proline and glycyl-L-proline in the small intestine of the human fetus. Pediatr. Res., 3: 313 (1969).

33. Schiller, C. M., Huang, T., and Heizer, W. D.: Isolation and characterization of four peptide hydrolases from the cytosol of rat intestinal mucosa. Gastroenterology, 72: 93 (1977).

34. Schmitz, J., Preiser, H., Maestracci, D., Ghosh, B. K., Cerda, J. J., and Crane, R. K.: Purification of the human intestinal brush border membrane. Biochim. Biophys. Acta, 323: 98 (1973).

35. Simon, P. M., Kedinger, M., Raul, F., Grenier, J. F., and Happen, K.: Developmental pattern of rat intestinal brush border enzymic proteins along the villus-crypt axis. Biochem. J., 178: 407 (1979).

36. Sjöström, H., Norén, O., Jeppesen, L., Staun, M., Svensson, B., and Christiansen, L.: Purification of different amphiphilic forms of a microvillus aminopeptidase from pig small intestine using immunoadsorbent chromatography. Eur. J. Biochem., 88: 503 (1978).

37. Sjöström, H., Norén, O., Josefsson, L.: Purification and specificity of pig intestinal prolidase. Biochim. Biophys. Acta, 327: 457 (1973).

38. Skovbjerg, H., Sjöström, H., Norén, O., and Gudmand-Høyer, E.: Immunoelectrophoretic studies on human small intestinal brush border proteins. A quantitative study of brush border enzymes from single small intestinal biopsies. Clin. Chim. Acta, 92: 315 (1979)

39. Smith, R. L., and Heizer, W. D.: Gamma-glutamyl transpeptidase of rat and human intestine: greater enhancement of activity by dipeptides than amino acids or longer peptides. Gastroenterology (Abstract), 72: 1134 (1977).

40. Svensson, B., Danielsen, M., Staun, M., Jeppesen, L., Norén, O., and Sjöström, H.: An amphiphilic form of dipeptidylpeptidase IV from pig small intestinal brush border membrane. Purification by immunoadsorbent chromatography and some properties. Eur. J. Biochem., 90: 489 (1978).

41. Wigger, H. J., and Stalcup S. A.: Distribution and development of angiotensin converting enzyme in the fetal and newborn rabbit. An immunofluorescence study. Lab. Invest., 38: 581 (1978).

42. Woodbury, R. G., Gruzensky, G. M., and Lagunoff, D.: Immunofluorescent localization of a serine protease in rat small intestine. Proc. Natl. Acad. Sci. U. S. A., 75: 2785 (1978).

43. Woodbury, R. G., and Neurath, H.: Purification of an atypical mast cell protease and its levels in developing rats. Biochemistry, 17: 4298 (1978).

44. This work was presented in part at the XIII Annual Meeting of the European Society for Paediatric Gastroenterology, Naples, Italy, May 28-29, 1980.

45. Requests for reprints should be addressed to: S. Auricchio, M. D., Clinica Pediatrica-II Facoltá di Medicina e Chirurgia, Universitá di Napoli, Via S. Pansini n.5, 80131 Napoli, Italy.

46. Received for publication April 11, 1980.

47. Accepted for publication October 20,1980 